\title{
Microbial food web responses to phosphorus supply and solar UV radiation in a subarctic lake
}

\author{
Mylène Bergeron, Warwick F. Vincent* \\ Département de biologie \& Centre d'études nordiques, Université Laval, Sainte-Foy, Québec, Canada G1K 7 P4
}

\begin{abstract}
We examined the effects of solar ultraviolet radiation (UVR) and phosphorus enrichment on microbial food web structure in a subarctic oligotrophic lake (Lac à l'Eau Claire, Canada; latitude $56^{\circ} 10^{\prime} \mathrm{N}$, longitude $74^{\circ} 30^{\prime} \mathrm{W}$ ) using replicated, 201 polyethylene containers incubated in situ. The experiments were run for between 6 and $9 \mathrm{~d}$ at the surface of the lake at 3 times during the summer open water period. Chlorophyll a (chl al production of the $>2 \mu \mathrm{m}$ fraction of the phytoplankton community was stimulated by $P$; this response was reduced on average by $31 \%$ in the presence of UV-A. and by an additional $29 \%$ in the presence of UV-B. Conversely the $<2 \mu \mathrm{m}$ chl a fraction declined with P enrichment, but to a lesser extent in the presence of UV-B. Cell counts of picocyanobacteria showed a decrease under P enrichment, with significantly greater declines induced by UV-A and additionally by UV-B. The nanoflagellate community increased in cell concentration in response to $P$ addition, but only in the absence of UV-A. Bacterial cell concentrations in the P enrichments remained close to or slightly above (up to $20 \%$ ) the initial values, but sharply declined in the treatments without $P$ addition; the positive effect of enrichment was not influenced by UV-A or by UV-B. This diverse array of responses implies that shifts in underwater UVR caused by changes in spectral penetration through the atmosphere (ozone depletion) or water column (changes in dissolved organic carbon) will influence microbial trophic structure as well as productivity within subarctic lakes. Such effects, however, will be limited to aquatic environments that are naturally exposed to high UVR such as shallow water columns or surface waters during diurnal stratification.
\end{abstract}

KEY WORDS: Microbial food webs Phosphorus P Polar S Subarctic lakes UV

\section{INTRODUCTION}

The continuing degradation of the Earth's ozone layer by atmospheric pollutants has generated concern about the impact of increasing solar ultraviolet- $B$ radiation (UV-B) on aquatic ecosystems, particularly at high latitudes where the relative increase in UV-B has been most pronounced. Although attention has mostly focused on Antarctica (Weiler \& Penhale 1994), there is increasing evidence of change in the UV-B flux at mid to high northern latitudes (Kerr 1994). The International Arctic Science Committee (IASC) has recently recommended that research on the impact of UV-B in Arctic ecosystems be given urgent priority (IASC 1995). The rise in UV-B appears to be proceeding rapidly at subarctic latitudes; for example, calculations

\footnotetext{
- Addressee for correspondence.

E-mail:warwick.vincent@bio.ulaval.ca
}

based on ozone column measurements at latitude $55^{\circ} \mathrm{N}$ show that the daily average spectral irradiance at $310 \mathrm{~nm}$ during spring and summer increased by 10 to $30 \%$ between 1979 and 1994 (Fig. 1 in IASC 1995).

Lakes and wetlands are major components of the subarctic environment. Most of these waters are oligotrophic (Smith et al. 1984, Stockner \& Shortreed 1991. Milot-Roy \& Vincent 1994) in which the plankton community is likely to be strongly nutrient-limited and dominated by microbial food web components. Ultraviolet radiation (UVR) penetrates deep into oligotrophic, low DOC (dissolved organic carbon) waters (Morris et al. 1995), and microbial responses to changes in phosphorus supply in these lakes (e.g. due to seasonal effects or changes in external nutrient loading) could thus be influenced by rising UV-B radiation as well as by natural variations in the UV-A + $U V-B$ radiation regime. The latter variations may be considerable in subarctic lakes because DOC lies 
within the range where small changes in concentration give rise to major shifts in spectral UVR (Vincent \& Pienitz 1996, Laurion et al. 1997).

UVR is photochemically the most active waveband of the solar spectrum and has a potentially broad range of effects on organisms within the aquatic microbial food web. The UV-B component ( 280 to $320 \mathrm{~nm}$ ) is known to inhibit primary productivity (Vincent \& Roy 1993, Cullen \& Neale 1994, and references therein), while UV-A (320 to $400 \mathrm{~nm}$ ) has been implicated in damage as well as repair processes (Quesada et al. 1995). Aquatic organisms have experienced large-scale variations in UVR throughout evolutionary time and have developed several types of defense against UVR damage (Vincent \& Roy 1993); however, there are major differences between species in the extent and cffectiveness of these defenses (e.g. Davidson et al. 1996). Some studies have shown that UV-B affects the motility and orientation of nanoflagellates (e.g. Nielsen \& Ekelund 1993, Hessen et al. 1995), key grazing components of the microbial food web. UV-B is known to inhibit nitrate, nitrite and phosphorus uptake by planktonic communities (Behrenfeld et al. 1995, Hessen et al. 1995). UVR can also affect planktonic organisms indirectly. For example, although UV-B may have damaging effects on bacterioplankton (e.g. Herndl et al. 1993, Müller-Niklas 1995), the photochemical interaction between UVR and humic substances can liberate nutrients and low molecular weight carbon substrates that are then available for microbial growth (e.g. Nielsen \& Ekelund 1993, Hessen \& van Donk 1994).

The effect of phosphorus enrichment on microbial food web structure is not well understood. There is evidence from a broad range of marine and freshwater sites that although bacteria are efficient competitors for inorganic phosphorus (Kirchman 1994), the growth of natural assemblages can be stimulated by P enrichment (Coveney \& Wetzel 1992, Elser et al. 1995). Some studies have shown that increased phosphorus loading favors a shift of the phytoplankton community from picoplankton towards nanoplankton (Takamura \& Nojiri 1994). Nanoplanktonic growth in oligotrophic waters can be strongly limited by phosphorus while the picoplankton remain phosphorus sufficient (Frenette et al. 1996), perhaps because of their high surface to volume ratio and nutrient scavenging ability (Suttle et al. 1987).

In the present study we evaluated the influence of UVR and phosphorus en- richment on microbial food web structure and dynamics in a subarctic lake. We hypothesized that the various trophic components of the microbial food web would differ in their response to increased phosphorus supply and that exposure to UVR would modify these responses. We tested this hypothesis by way of replicated, small-scale (20 I) bioassays that were incubated in situ during the summer open water period of the lake.

\section{METHODS}

Study site. Sampling and incubations were performed at Lac à l'Eau Claire (Clear Water Lake), a large $\left(1269 \mathrm{~km}^{2}\right)$, oligotrophic lake $(0.2$ to $2.0 \mu \mathrm{g} \mathrm{chl} \mathrm{a}$ $\mathrm{I}^{-1}$ ) located in the subarctir region of Québec. Canada, $150 \mathrm{~km}$ inland from Hudson Bay (Fig. 1). Experiments were conducted in a small bay of an island situated in the central Western Basin of the lake (mean depth of the Western Basin is $24.5 \mathrm{~m}$ ). This bay was protected against the westerly and southwesterly winds which predominate over Lac à l'Eau Claire during summer (Arsenault 1993)

Chemical and physical measurements. Near-surface water samples were collected for chemical analysis using a Van Dorn water sampler and transferred to polyethylene bottles after filtration through a $0.22 \mu \mathrm{m}$ Sartorius cellulose acetate membrane. These samples were stored cold $\left(4^{\circ} \mathrm{C}\right)$ until analysis by the National Water Research Institute (Burlington) using standard methods (Environment Canada 1994). Profiles of temperature fine struc-

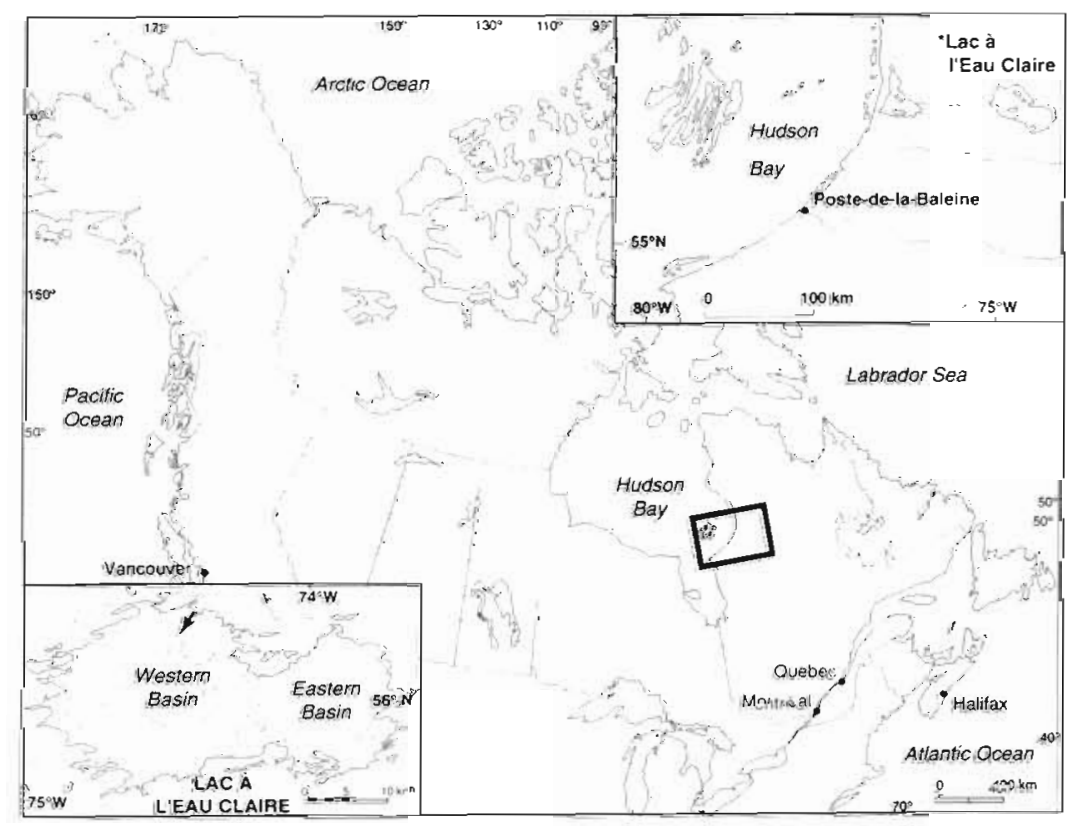

Fig. 1. Location of Lac à l'Eau Claire in northern Québec, Canada. The arrow in the lower left inset marks the position of the study site in the Western Basin 
ture, UVR and photosynthetically active radiation (PAR) were obtained with a PUV-500 underwater profiler (Biospherical Instruments Inc., San Diego, CA, USA).

Bioassay protocol. The effect of nutrient enrichment and different UVR regimes on trophic structure was measured using a floating, replicated bioassay system. Samples (20 l) of lakewater from $0.5 \mathrm{~m}$ depth were incubated in polyethylene Cubitainers ${ }^{\mathrm{TM}}$ held within 2 support structures moored next to each other. The water was not prefiltered, but sampling was during daylight hours (within the period 11:30 to $15: 00 \mathrm{~h}$ for all experiments) when near-surface concentrations of large migrating zooplankton are likely to be reduced. The Cubitainers were vigorously rinsed 3 times with the surface lakewater before filling. Each of the moorings consisted of a wooden frame $(107 \times 208 \times 76 \mathrm{~cm})$ separated into 8 compartments and maintained at the water surface by buoys. Of the 16 compartments, 12 held a Cubitainer extending from 15 to $45 \mathrm{~cm}$ depth and were covered by 1 of 3 types of filters attached to the wooden support: UF3 Plexiglas (allows PAR but no UVR to pass), Dupont Mylar-D (PAR and UV-A) or UVT Plexiglas (PAR and UVR). The Cubitainer polyethylene caused a small $(<15 \%)$ relatively uniform loss across the UVR and PAR wavebands (spectral transmission curves for polyethythene and the 3 filter types used here are given in Fig. 9 of Prézelin et al. 1994), and the differences in UV-A versus UV-B penetration were primarily the result of spectral attenuation by the lakewater. The mean in situ UVR values within the Cubitainers in the UVT treatments (incorporating the effect of filters, the Cubitainer and the integral UVR for the water column from 15 to $45 \mathrm{~cm}$ ) were $30 \%$ of surface UV-B (305 nm) and $70 \%$ of surface UV-A (340 nm). Meteorological conditions were highly variable from day to day during the incubations, ranging from full sun (up to $1800 \mu \mathrm{mol} \mathrm{m} \mathrm{m}^{-2} \mathrm{~s}^{-1} \mathrm{PAR}$ and $25 \mu \mathrm{W} \mathrm{cm} \mathrm{cm}^{-2} \mathrm{~s}^{-1}$ UVR at $320 \mathrm{~nm}$ ) to scattered cloud and overcast

Each filter treatment was enriched with low levels of inorganic phosphorus $\left(1 \mu \mathrm{g} \mathrm{P} \mathrm{^{-1 }}\right.$ final conc. $\mathrm{d}^{-1}$, added as $\mathrm{K}_{2} \mathrm{HPO}_{4}$ ), and a control UVT treatment was run without phosphorus. The $\mathrm{P}$ solution was added at Days 0,3 and 6 , immediately after the sampling of the Cubitainers. All treatments were conducted in triplicate (i.e. 3 Cubitainers per treatment). The bioassays were conducted at 3 times during the summer season, beginning 29 July (Expt 1), 7 August (Expt 2), and 13 August (Expt 3) 1994. There was little change in microbial food web structure in the lake through the course of this sampling period and for the subsequent statistical analyses we therefore treated the 3 sets of bioassays as replicate experiments.

Measurement of microbial food web components. Every 3 d a 1 l sample of water was taken from each Cubitainer to evaluate chlorophyll a (chl a) concentra- tion and to determine the cell concentrations of bacteria, picocyanobacteria and nanoplankton. Samples were maintained under cool, dark conditions within an icebox for up to $4 \mathrm{~h}$ before sample filtration and preservation. For each type of enumeration a minimum of 400 cells were counted in each sample.

$\mathrm{Chl}$ a was estimated for the total phytoplankton and picophytoplankton fraction $(<2 \mu \mathrm{m})$. For the latter, subsamples of water were prefiltered through a $4.7 \mathrm{~cm}$ diameter, $2 \mu \mathrm{m}$ pore-size Nuclepore filter Samples $(100 \mathrm{ml})$ of the lakewater with and without prefiltration were then filtered onto $25 \mathrm{~mm}$ Whatman glass microfiber filters (grade GF/F, $2.5 \mathrm{~cm}$ diameter) under low vacuum pressure and stored frozen. Chl a was subsequently analyzed 3 to $4 \mathrm{~d}$ later by extraction in boiling ethanol (Nusch 1980) and then fluorometry. Samples were measured before and after acidification with a Sequoia Turner Model 450 fluorometer equipped with NB440 (blue excitation) and SC665 (red emission) filters. The fluorometer was calibrated on each date of measurement with standard chl a from Anacystis nidulans (Sigma Chemical Co.) assayed spectrophotometrically.

Bacterial samples were transferred to scintillation vials $(20 \mathrm{ml})$ and preserved with formaldehyde $(4 \%$ final conc.). These were stored in the dark at $4^{\circ} \mathrm{C}$ for up to several weeks and then stained with the fluorochrome 4',6-diamidino-2-phenylindole (DAPI) and filtered through $25 \mathrm{~mm}$ diameter, $0.22 \mu \mathrm{m}$ pore-size, black Nuclepore membranes for counting by epifluorescence microscopy (Porter \& Feig 1980). Additional samples for autotrophic picoplankton $(125 \mathrm{ml})$ were preserved with paraformaldehyde $10.2 \%$ final conc.; Hall \& Vincent 1990), and $50 \mathrm{ml}$ subsamples were later filtered onto black Nuclepore filters $25 \mathrm{~mm}$ diam., $0.22 \mu \mathrm{m}$ pore size) for enumeration by epifluorescence.

The phytoplankton/nanoflagellate samples $(250 \mathrm{ml})$ were fixed immediately after collection with $1 \%$ glutaraldehyde and $0.1 \%$ paraformaldehyde final concentrations (Tsuji \& Yanagita 1981) and stored in the dark at $4^{\circ} \mathrm{C}$. For enumeration, the samples were gently mixed by inversion and $100 \mathrm{ml}$ subsamples removed. These were sedimented for $48 \mathrm{~h}$ in a $2.6 \mathrm{~cm}$ diameter Utermöhl settling chamber, stained with DAPI, and then examined by the fluorescence-UtermöhlNomarski method as in Lovejoy et al. (1993).

Data analysis. Statistical analyses were performed with the software package SuperANOVA (Abacus Concepts). In the first experiment we noted a major decline in microbial populations at Day 9 (see below) suggestive of severe container effects. We therefore terminated subsequent experiments at Day 6. For data analysis the pooled Day 6 values for all 3 experiments were examined by 2 -way analysis of variance (ANOVA) after verifying normality and homogeneity of variance. Post hoc analysis was then performed 
using the Tukey-Kramer test (see Driscoll 1996) to identify significant treatment, experiment and interaction effects.

\section{RESULTS}

\section{Chemical and physical environment}

The surface waters at the study site were characterized by dilute concentrations of major ions and nutrients (Table 1). Soluble reactive phosphorus (SRP) concentrations were at the limits of detection $(0.2 \mu \mathrm{g} \mathrm{SRP}$ $\mathrm{I}^{-1}$ ) and the inorganic N:P ratio (by weight) was over 100 , indicative of phosphorus deficiency. Similar nutrient concentrations wete funinu at other sites in Las à l'Eau Claire, indicating that the bioassay site was representative of much of the lake.

The bay was too shallow ( $3 \mathrm{~m}$ maximum depth) to be seasonally stratified, but weak diurnal stratification was sometimes observed. In the Western Basin further offshore from the study site, a seasonal thermocline formed at 12 to $16 \mathrm{~m}$ depth and varying degrees of diurnal stratification were apparent in the near-surface waters (Fig. 2).

DOC concentrations in Lac à l'Eau Claire during the period of study were 2 to $3 \mathrm{mg} \mathrm{C \textrm {Cl } ^ { - 1 }}$ (Table 1), allowing relatively deep penetration of the UVR and PAR wavebands (Fig. 2). The downwelling radiation levels (as \% surface radiation) at the bottom of the bay $(3 \mathrm{~m})$ were $0.04 \%$ (305 nm), 0.5\% (320 nm), 1.8\% (340 nm), 13\% (380 nm) and $55 \%$ (PAR). A more detailed bio-optical description of Lac à l'Eau Claire is given in Laurion et al. (1997).

Table 1. Chemical characteristics of the study site bay relative to other locations at Lac à l'Eau Claire, late July 1994 (C5: sidebay of the Western Basin, Baie Pacatouk; C6: offshore site in the Eastern Basin; C22: offshore site in the central Western Basin). DOC: dissolved organic carbon; SRP: soluble reactive phosphorus; TKN-F: total Kjeldahl nitrogen in filtrates; TP-F: total phosphorus in filtrates; TP-UF: total phosphorus in unfiltered water; TIN: total inorganic nitrogen

\begin{tabular}{|c|c|c|c|c|c|}
\hline & & Bay & C5 & C6 & $C 22$ \\
\hline DOC & $\left(\mathrm{mg} \mathrm{l}^{-1}\right)$ & 2.33 & 2.87 & 2.57 & 2.23 \\
\hline $\mathrm{Cl}^{-}$ & $\left(\mathrm{mg} \mathrm{l}^{-1}\right)$ & 0.87 & 0.90 & 0.88 & 0.78 \\
\hline $\mathrm{SiO}_{2}$ & $\left(m g 1^{-1}\right)$ & 0.49 & 0.99 & 0.82 & 0.50 \\
\hline $\mathrm{SO}_{4}{ }^{2-}$ & $\left(\mathrm{mg} \mathrm{I}^{-1}\right)$ & 1.70 & 1.70 & 1.70 & 1.60 \\
\hline SRP & $\left(\operatorname{lgg~}^{-1}\right)$ & 0.2 & 0.2 & 0.2 & 0.2 \\
\hline $\mathrm{NO}_{3}{ }^{-}-\mathrm{N}$ & $\left(\mu g \mathrm{l}^{-1}\right)$ & 16.0 & 10.0 & 49.0 & 34.0 \\
\hline $\mathrm{NH}_{3}-\mathrm{N}$ & $\left(\mu g l^{-1}\right)$ & 9.0 & 11.0 & 8.0 & 10.0 \\
\hline TKN-F & $\left(\mu g l^{-1}\right)$ & 69.0 & 94.0 & 55.0 & 69.0 \\
\hline TP-F & $\left(\mu g l^{-1}\right)$ & 2.1 & 1.8 & 0.8 & 1.9 \\
\hline TP-UF & $\left(\mu g l^{-1}\right)$ & 3.7 & 4.4 & 2.4 & 2.9 \\
\hline TIN:SRP & $(\mu g: \mu g)$ & 125 & 105 & 285 & 220 \\
\hline
\end{tabular}

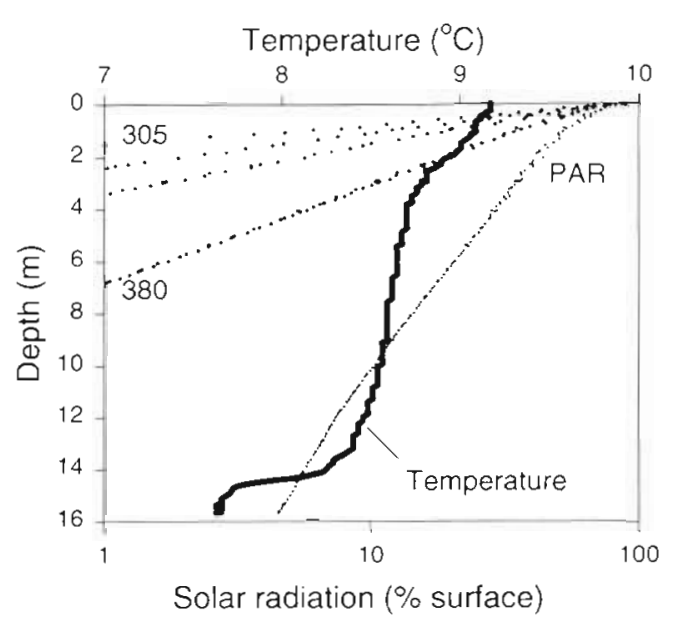

Fig. 2. Mrotiles of temperdiule, U'V'R and PAR with dopth at a station $300 \mathrm{~m}$ directly east of the study site, on 8 August 1994 The 4 measured UVR wavelengths were (in order of increasing penetration through the water column): 305, 320, 340 and $380 \mathrm{~nm}$

\section{Bacteria}

In Expt 1, bacterial densities decreased over time in the UVT-P incubation (UVT minus phosphorus enrichment, denoted below as UVT-P) but remained close to or above the initial concentrations in the P enrichment (Fig. 3a). By Day 6 the concentrations of bacteria in the P enrichments were significantly $(\mathrm{p}<0.05)$ higher than in the UVT-P control, with no significant differences between the 3 UVR filter treatments. By Day 9 a UV-B effect was apparent, with bacterial densities that were significantly $(p<0.05)$ lower in the total radiation (UVT-P and UVT $+P$ ) treatments relative to treatments without UV-B (Mylar+P) or without full waveband UVR (UF3+P).

Two-way ANOVA for the bacterial data from all 3 experiments at Day 6 (Fig. 4a) showed that there were significant differences between treatments $(p=0.0001)$ and between the 3 experiments $(p=0.0001)$; the interaction term for this ANOVA (treatments $x$ experiments) was not significant $(p=0.21)$. There were significant differences between the UVT-P and all the other treatments (Tukey-Kramer test; $\mathrm{p}<0.01$ ), with a mean value for bacterial density in this unenriched control that was 35 to $43 \%$ below the P-enriched treatments. There were no significant differences between filter conditions within the set of $P$ enrichments.

\section{Phototrophic picoplankton}

In contrast to the bacterial response, the density of picocyanobacteria dropped after $\mathrm{P}$ addition, but to an extent that depended on the UVR regime (Fig. 3b). 
Cell concentrations in the UVT treatment changed little through the course of Expt 1 but in the UVT+P treatment, values dropped by 17 to $46 \%$ This decline was less marked when UV-B was filtered out by Mylar ( 7 to $24 \%$ ) and was eliminated when both UV-A and UV-B wavebands were removed (UF3+P).

The 2-way ANOVA of the Day 6 counts for the 3 experiments (Fig. 4 b) showed that there were significant differences between treatments $(p=0.0008)$ and experiments $(p=$ $0.0001)$, with no significant interaction between experiments and treatments $(\mathrm{p}=$ 0.79). Unlike the bacterial communities, the picocyanobacteria were significantly (TukeyKramer test; $\mathrm{p}<0.05)$ more abundant in the UVT-P than in the P-enriched treatments (Fig. 4b). UVR modified this response with the least inhibitory effect of $P$ in the PARonly treatment, and greatest inhibitory effect induced by UV-A plus UV-B.

\section{Nanoplankton}

In Expt 1 the total nanoplankton densities showed little change between Days 0 and 6 , with the notable exception of the UF $3+\mathrm{P}$ treatment, in which there was an increase to significantly ( $p<0.05$ ) higher values (Fig. $3 c$ ). There was then a sharp decline in the nanoplankton concentration in all treatments between Days 6 and 9 .

The 2-way ANOVA for total nanoplankton densities at Day 6 showed significant differences between treatments $(p=0.0001)$ and between experiments $(p=0.0001)$, and there was a significant interaction between experiments and treatments ( $\mathrm{p}=0.0322$ ). The abundance of nanoplankton (Fig 4c) was significantly (Tukey-Kramer test; $\mathrm{p}<0.01$ ) higher in the $\mathrm{UF} 3+\mathrm{P}$ treatment than in the other treatments, indicating that UV-A inhibited this component of the microbial community.

Nanoflagellates were responsible for most of the trends observed in the total nanoplankton community (Fig. 3d). From the beginning of Expt 1 up to Day 6, the densities for the UF3+P treatment increased by $75 \%$, and there was a significant difference $(p<0.05)$ at this time between UF3+P and the other treatments.

The 2-way ANOVA for nanoflagellate data at Day 6 (Fig. 4d) showed significant differences between treatments $(p=0.0001)$ and between experiments $(p=0.0062)$; the inter-
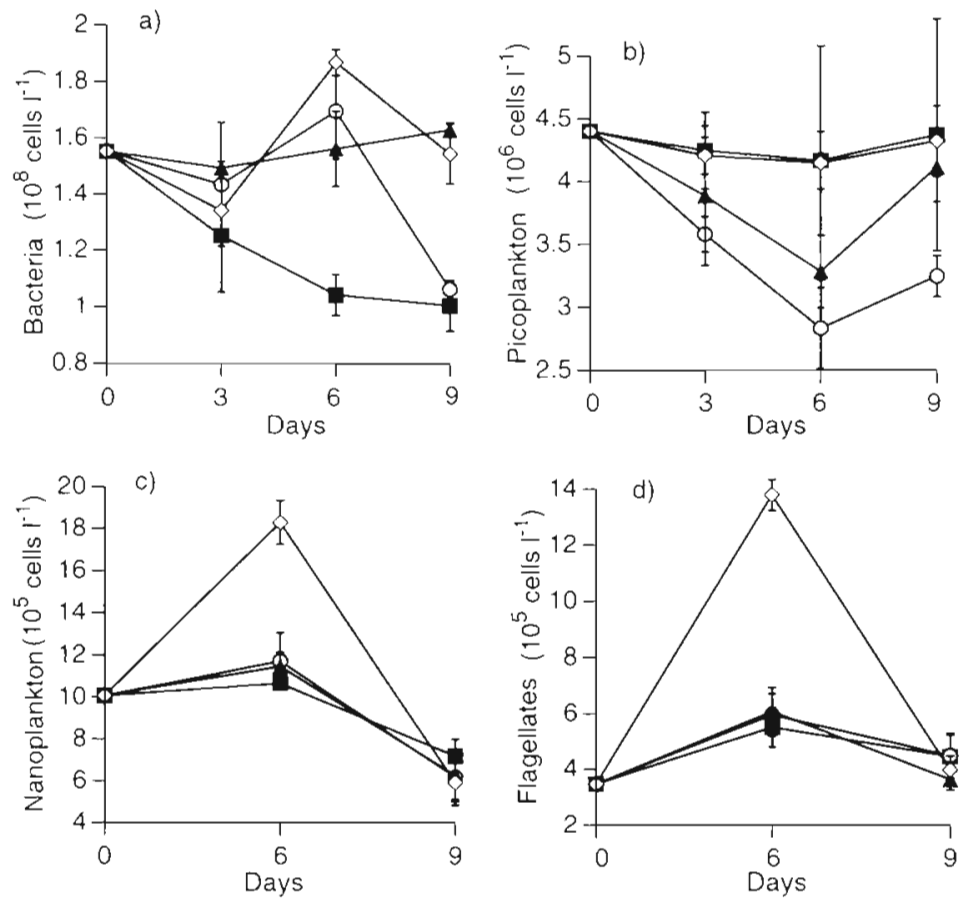

Fig. 3. Microbial food web components through time in Expt 1 Each value represents the mean of triplicates $( \pm$ SE) for UVR+PAR-P (UVT-P, -): UVR+PAR+P (UVT+P, O): UV-A+PAR+P (Mylar+P, $\Delta)$ and PAR+P $(\mathrm{UF} 3+\mathrm{P}, \diamond)$. (a) Bacteria; (b) picoplankton refers to picocyanobacteria; (c) nanoplankton refers to all DAPI-stained cells in the range 2 to $20 \mu \mathrm{m}$; and (d) flagellates refers to autotrophic plus heterotrophic nanoflagellates in the size range 2 to $20 \mu \mathrm{m}$
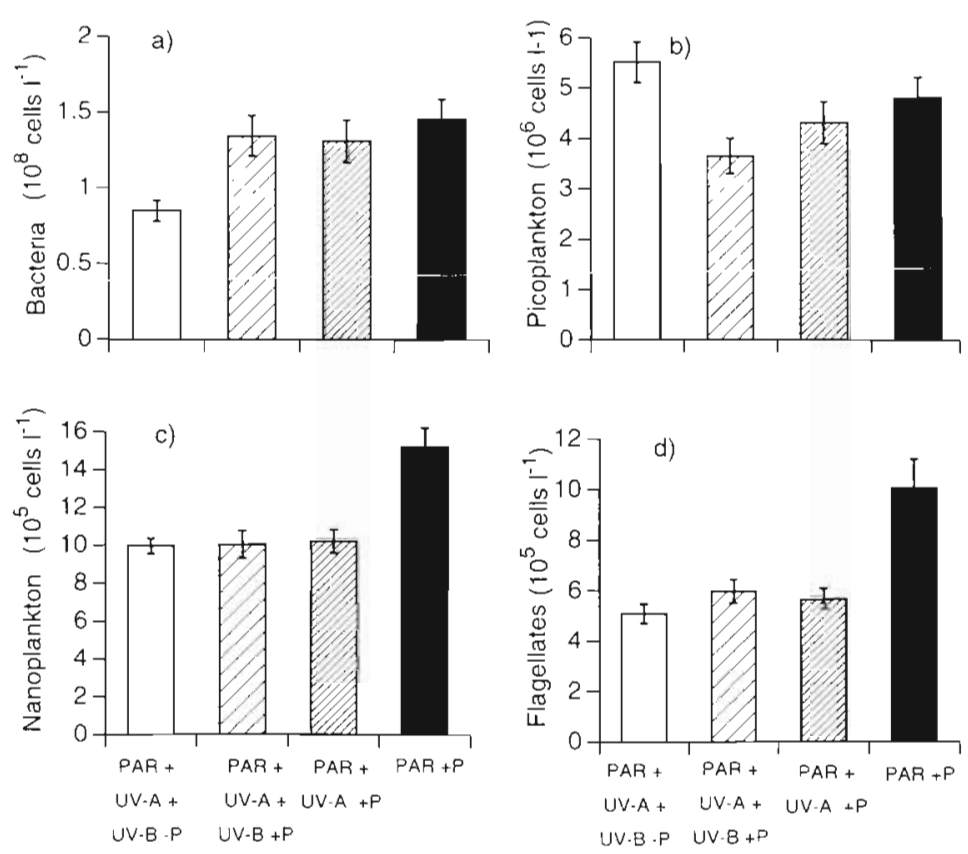

Fig. 4. Microbial food web components after $6 \mathrm{~d}$ of incubation. Each value is the mean $( \pm S E ; n=9$ ) for the 3 experiments. ( $a-d)$ as in Fig. 3 legend 

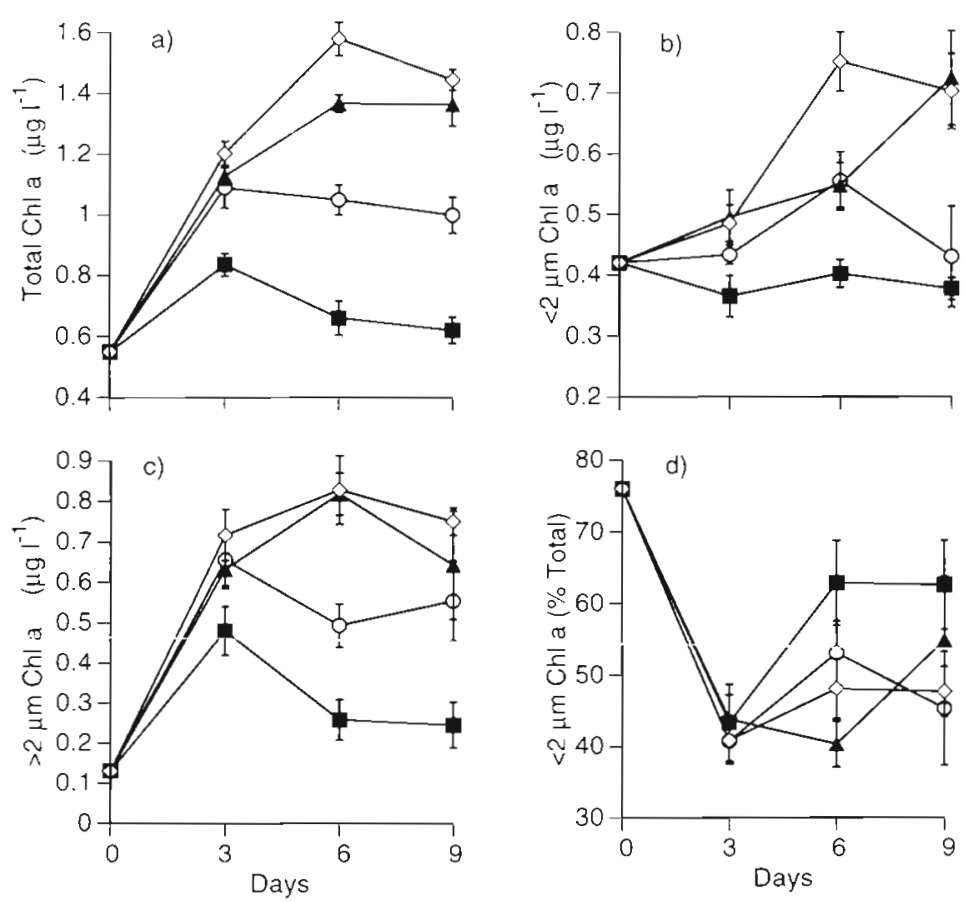

Fig. 5. Chl $a$ in different size fractions through time in Expt 1. Each value represents the mean of triplicates $( \pm S E$ ) for UVR+PAR-P (UVT-P, - $)$ UVR+PAR+P (UVT+P, O); UV-A+PAR+P (Mylar+P, $\Delta)$ and PAR+P $(U F 3+P, \circ)$. (a) Total chl $a$, (b) $<2 \mu \mathrm{m}$ size fraction and (c) $>2 \mu \mathrm{m}$ size fraction concentrations, and (d) $<2 \mu \mathrm{m}$ size fraction as \% of total chl a
The 2-way ANOVA for the pooled total chl a data at Day 6 (Fig. 6a) showed that there were significant differences between treatments $(p=0.0001)$, but not experimenls $(\rho=$ 0.08 ). There was also a significant interaction (treatments $\times$ experiments; $p=0.0009$ ). The concentration of total chl a was significantly (Tukey-Kramer test; $\mathrm{p}<0.01$ ) higher in the UF3 treatment than in the other treatments, indicating UV-A inhibition. The mean values for total chl $a$ in the UVT-P treatment was 32 to $48 \%$ below concentrations in the Penriched treatments, indicating that the total community responded to phosphorus enrichment. The full UVR waveband also had an effect on total rhl a as evidenced by siqnificant differences between UF3+P and the other filter treatments (Tukey-Kramer test; $p<0.01$ ), and indicating the overall dominating effect of UV-A.

In Expt 1, chl a concentration in the $<2 \mu \mathrm{m}$ fraction changed little with time throughout the UVT-P incubation (Fig. 5b). In the Penriched treatments, the concentrations generally increased up to $6 \mathrm{~d}$ and then decreased slightly after $9 \mathrm{~d}$ with the exception of the Mylar+P treatment which increased over the full $9 \mathrm{~d}$ incubation. At Day 6 the mean value for picoplanktonic chl a concentration in the action term for this ANOVA (treatments $x$ experiments) was also significant ( $\mathrm{p}=$ $0.0063)$. The abundance of nanoflagellates was significantly (Tukey-Kramer test; p < 0.01 ) higher in the UF3+P treatment than in the other treatments, with values 68 to $98 \%$ above other treatments, indicating a strong effect of UV-A as for the total nanoplankton community.

\section{Chl a}

Total chl a showed little change with time in the UVT-P incubation for Expt 1 (Fig. 5a). For the other treatments, the concentration generally increased up to $6 \mathrm{~d}$, with no change or a decline from Days 6 to 9. There was a strong positive effect of phosphorus addition throughout this experiment with significant differences $(\mathrm{p}<0.05)$ between UVT-P and all $+P$ treatments on all days. In addition to the phosphorus effect, beyond Day 3 (i.e. at Days 6 and 9 ) there was significant $(p<0.05)$ inhibition by UV-A, and greater inhibition by UV-A plus UV-B.
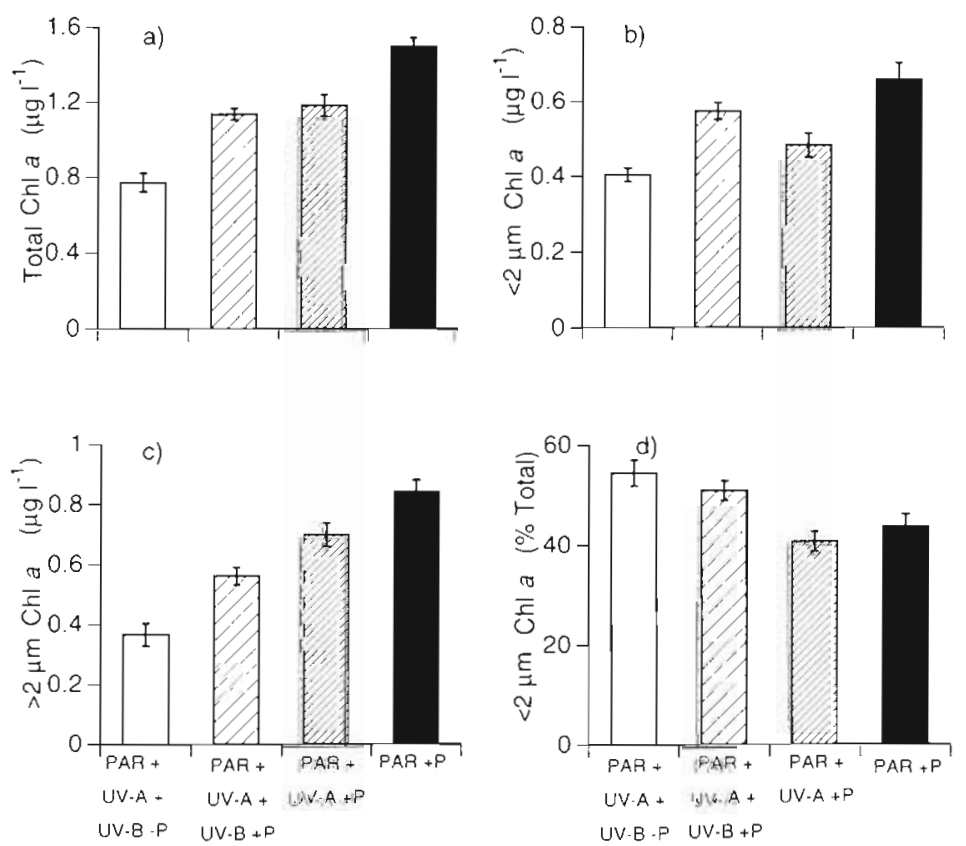

Fig. 6. Chl $a$ in different size fractions after $6 \mathrm{~d}$ of incubation. Each value is the mean $\left( \pm \mathrm{SE}_{i} \mathrm{n}=9\right.$ ) for the 3 experiments. (a-d) as in Fig. 5 legend 
UF3 $+\mathrm{P}$ treatment was significantly $(p<0.05)$ higher than the other $+\mathrm{P}$ treatments, indicating an inhibitory UV-A effect. By Day 9 there was no significant difference between UF3 and Mylar; these 2 treatments were both significantly above UVT+P, implying that UVR effects near the end of the experiment were dominated by UV-B

The 2-way ANOVA for picoplanktonic chl a data at Day 6 (all 3 experiments) showed significant differences between treatments ( $p=0.0001$ ) but no significant experiment or interaction effect $(p=0.13$ and $p=$ 0.07 , respectively). Picoplanktonic chl a was lowest in the UVT-P control (Fig. 6b). There were significant differences between UVT-P and UVT $+P$, between UVT-P and $\mathrm{UF} 3+\mathrm{P}$, and between Mylar+P and UF3+P treatments (Tukey-Kramer test; $\mathrm{p}<0.01$ ), but no significant $(p>0.05)$ differences between UVT $+P$ and UF3+P. These results show an overall phosphorus stimulation effect and a resistance to UV-A. The mean value for Mylar+P was 16 to $27 \%$ below the other phosphorusenriched treatments indicating a possible stimulatory effect of UV-B in the presence of UV-A

The large-cell fraction (>2 $\mathrm{\mu m}$ ) of chl a increased over the first $3 \mathrm{~d}$ of incubation in all treatments in Expt 1 and then remained relatively stable (P-enriched treatments) or declined (UVT-P) (Fig. 5c). Chl $a$ in this fraction was significantly $(p<0.01)$ reduced in the presence of UV-A by Day 6 . The 2-way ANOVA for the $>2 \mu \mathrm{m}$ fraction in the 3 experiments at Day 6 showed significant differences between treatments $(\mathrm{p}=$ 0.0001 ), and a significant interaction between experiments and treatments ( $p=0.0132)$. The concentration in large phytoplankton chl a (Fig. 6c) was significantly (Tukey-Kramer test; $\mathrm{p}<0.01$ ) lower in the UVT-P treatment than in the P-enriched treatments, indicating a growth response to phosphorus. A UVR effect on large phytoplankton chl a is also apparent, with significant differences between all light treatments (TukeyKramer test; $\mathrm{p}<0.05$ ). The concentration of this chl a fraction increased with the removal of UV-B (Mylar+P) and further increased when UV-A was also removed (UF3+P)

The time course of picoplankton chl a as a percentage of total chl a in Expt 1 (Fig. 5d) showed a strong decrease by Day 3, with no significant treatment effects at this time. There were significant differences $(p<0.05)$ between UVT and Mylar+P treatments after $6 \mathrm{~d}$, but no additional effects at Day 6 or Day 9. The 2-way ANOVA of these percentages for all 3 experiments at Day 6 showed significant differences between treatments $(p=0.0001)$, and experiments $(p=0.035)$, but no interaction effect. The percent picoplankton chl a was significantly (Tukey-Kramer test; $\mathrm{p}<0.01$ ) higher in the unenriched control than in the Mylar+P and UF3+P treatments (Fig. 6d), with mean values 7 to
$34 \%$ above these 2 treatments. UV-B also had an effect on the ratio (significant differences between UVT+P and Mylar+P: $p<0.01$ ). These results indicate that the percent contribution of the picoplankton fraction to total chl a was highest when phosphor us was limiting in the presence of UV-B.

\section{DISCUSSION}

\section{Container effects}

The bioassay protocol adopted here provided a convenient approach towards assaying the effects of physical and chemical variables on the microbial food web. While a great variety of enclosure sizes have been used in the aquatic sciences, ranging from small botthes to large mesocosms containing $>100 \mathrm{~m}^{3}$, the experimental volume is best scaled to the size and abundance of the biota under study. Our microcosms lacked the dimensions of large lake enclosures (e.g. Andersson et al. 1994); however, the 201 volumes were replicated and contained large numbers of the organisms of interest for the present study: $10^{6}$ nanoplankton, $10^{7}$ picocyanobacteria and $10^{9}$ bacterial cells per Cubitainer. This size would thus seem appropriate for microbial food web studies.

Although the floating microcosms provided a valuable bioassay tool, the organisms experienced certain conditions that deviated from the natural lake environment. Firstly, there were changes in the relative proportion of the different wavebands, with a slightly greater attenuation of UV-B. The UV results are therefore likely to be conservative relative to conditions at the very surface of the lake (but see below) Secondly, the Cubitainers cut off advective and diffusive nutrient inputs; this may have exaggerated the stimulatory effects of phosphorus. In bioassays with marine phyloplankton, UV-B effects were observed with enriched but not unenriched samples (Behrenfeld et al. 1994). This suggests that nutrient stress can reduce or perhaps mask the effects of UV-B stress, although there is also evidence to the contrary (Cullen \& Lesser 1991). Thirdly, our Cubitainer bioassay system maintained the community under test at a specific depth, and prevented the deep circulation of cells by turbulent diffusion within the mixed layer. However, such conditions can occur naturally in lake systems, including Lac à l'Eau Claire. Diurnal thermoclines which prolong the residence time of phytoplankton near the surface have been previously observed in this lake (Milot-Roy \& Vincent 1994) and were also noted during the present study (Fig. 2)

Like all enclosure experiments, the microcosms used in the present study could promote an artificial succes- 
sion via the selection of certain species. For example, Pérez-Martinez \& Cruz-Pizarro (1995) found that phosphorus enrichment of enclosures affected phytoplankton community structure indirectly by promoting silicate limitation of Cyclotella ocellata, and causing a shift towards flagellate dominance. The low silica levels in Lac à l'Eau Claire would similarly prevent a substantial diatom response to P-only enrichment. Container wall effects and the elimination of certain loss processes (e.g. sinking, grazing by migrating zooplankton) may also contribute towards unusual species shifts. We attempted to minimize such effects by using short ( 6 to 9 d) incubation times. The grazer losses to crustacean herbivores, however, is likely to have been artificially low because we filled the containers with surtace water during line ladylight hours when migrating zooplankton tend to be at greater depth in the water column.

A potential toxicity effect of some plastics (Whirlpak polyethylene bags) has been identified by HolmHansen \& Helbling (1993) in their assay of photosynthetic responses to UVR. Prézelin et al. (1994) could find no evidence of such effects in their assays with Whirlpaks and attributed the earlier finding to differences in container geometry between the UVR treatments and control. Similarly, in our previous work at Lac à l'Eau Claire there was no apparent toxicity effect of Whirlpak polyethylene on photosynthesis (MilotRoy \& Vincent 1994), but we have not made similar tests on the Cubitainers. These latter incubation containers have a much smaller surface to volume ratio than the Whirlpaks. The strongly positive responses to $P$ enrichment found in the present study further suggests that there was little or no inhibition by the container wall material in these assays.

\section{Phosphorus effects}

All dissolved nutrients are in dilute concentration in oligotrophic lakes across the Precambrian Shield, but in these waters phosphorus has consistently emerged as the most limiting factor for phytoplankton biomass (Schindler et al. 1990). Phosphorus has been considered the primary limiting factor in lakes throughout Canada, including lakes in the Experimental Lakes Area, northwest Ontario (Schindler 1974), an oligotrophic lake in British Columbia (Suttle et al. 1987), subarctic lakes near Schefferville (Smith et al. 1984), and lakes in the Canadian high Arctic (Kalff \& Welch 1974). Our results are in accord with other sites within this North American region, although microbial responses have been little addressed in previous studies.

Phosphorus enrichment resulted in a decrease in picocyanobacterial abundance and an increase in the nanoplankton fraction. This effect is consistent with observations at lower latitudes (Takamura \& Nojiri 1994, Frenette et al. 1996) and may reflect the superior nutrient scavenging ability of picupldnkton at low substrate concentrations (Suttle et al. 1988) and the competitive advantage of larger cells under $P$ enrichment because of their potentially larger storage capacity (Suttle et al. 1987). In the Schefferville lakes, Smith et al. (1984) found that once phosphorus additions were made, the algae were unable to increase in biomass because of an induced nitrogen limitation. This type of secondary nutrient limitation may have caused the decline in biomass (if growth rates fell below loss rates) that we observed at Day 9 in Expt 1, given the low nitrate and ammonium values in Lac à l'Eau Claire.

Our results show that phosphorus enrichment can influence several components of the microbial food web in addition to phytoplankton and thereby cause a change in food web structure. Addition of phosphorus allowed the initial concentrations of bacteria to be maintained or to slightly increase, while cell concentrations declined sharply in the absence of added phosphorus; i.e. in the absence of $P$, bacterial growth rates were unable to keep pace with loss processes such as grazing by microzooplankton. These findings are consistent with observations in other aquatic ecosystems of P-limited bacterial growth (e.g. Coveney \& Wetzel 1992). It is possible, however, that our results reflect secondary effects, e.g. P-stimulated phytoplankton growth and thus increased algal release of DOC as a substrate for bacteria.

Phosphorus fertilization of the UVT treatment caused a decrease in biomass in phototrophic picoplankton, while nanoplankton cell counts remained unchanged. These results are consistent with a shift to nanoplankton dominance in the phytoplankton community in response to nutrient enrichment (Wehr 1989, Takamura \& Nojiri 1994). However, there was an increase in all chl a biomass fractions with phosphorus input, indicating a physiological adjustment to improved growth conditions and a shift towards species with a higher quantity of cellular chl $a$. Changes in the microbial grazers may have contributed to the decline in picocyanobacterial abundance. For example, in unfertilized Saqvaqjuac lakes, Canada, small protozoa dominated whereas after nutrient enrichment much larger species became dominant (Welch et al. 1989). The rise in nanoflagellate concentrations in the Lac à l'Eau Claire bioassays would be consistent with increased grazing pressure on the picoplankton fraction. The relative shifts in cell counts versus chl a, however, may also reflect the errors associated with phytoplankton cell enumerations and with size fractionation of pigment samples. 


\section{Ultraviolet radiation effects}

The various trophic components of the microbial food web in Lac à l'Eau Claire differed in their qualitative as well as quantitative responses to UVR. Bacteria in these waters were not sensitive to UVR in that the 6 d response to $P$-enrichment was not influenced by filter type. This observation is inconsistent with several reports in the literature that UV-B inhibits bacterial metabolism and growth (Bothwell et al. 1993, Herndl et al. 1993), although this effect may have contributed to the decline in bacteria observed at the very end of Expt 1. UVR exposure can promote the breakdown of organic macromolecules, releasing nutrients $(C, N, P$, $\mathrm{Fe}$ ) that could stimulate microbial activity (Hessen \& van Donk 1994), but the decline in bacterial numbers in the UVT-P control indicates that any photochemically mediated nutrient release was unable to compensate for the effects of nutrient deficiency. The DAPIbased estimates of bacterial concentrations in the present study probably included many inactive and non-functional cells (Zweifel \& Hagström 1995, Lovejoy et al. 1996). This may have masked certain responses, although the differences between $\mathrm{P}$ treatments in these experiments imply that a substantial fraction of the particles stained by DAPI is subject to active production and loss processes.

Unlike bacteria, the cell concentrations of picocyanobacteria were significantly reduced in the presence of UVR, and both UV-A and UV-B contributed to this decline. Although as a group cyanobacteria are known to have a broad range of protection and repair defenses against UVR, there are large variations in UVR resistance between species (Vincent \& Quesada 1994). Nanoflagellate abundance was also influenced by UVR regime, with the effects dominated by UV-A. Similarly, UVR affected total chl a concentration with greatest inhibition in the UV-A waveband, while the $>2 \mu \mathrm{m}$ fraction was inhibited by UV-B and further by UV-A. This latter component of solar radiation has been previously identified as dominating photoinhibition in the near-surface waters of Lac à l'Eau Claire because of the high incident solar flux in this waveband relative to UV-B (Milot-Roy \& Vincent 1994). The toxic effects of UVR on nanoflagellates have been well demonstrated in culture studies, although most reports have focused on UV-B (e.g. Nielsen \& Ekelund 1993, Hessen et al. 1995).

Our results underscore the need for an improved ecosystem-level understanding of the potential effects of changing underwater spectral UVR associated with ozone depletion or shifts in DOC concentration. Most studies to date have focused on the response of individual planktonic species. For example Smith et al. (1992) found that UV-B inhibition of growth rates was much greater for Phaeocystis spp. than for a clone of the diatom Chaetoceros socialis. Karentz et al. (1991) found that smaller diatom cells with a greater surface/ volume ratio were more sensitive to UV-B than larger cells. Observations of this type have led many authors to suggest that ozone depletion will result in a change in community structure whereby UV-B sensitive species will be replaced by more resistant taxa (Karentz 1991, Vincent \& Roy 1993, Behrenfeld et al. 1994). However, there are few studies at an ecosystem or community level (Bothwell et al. 1993). Our results with natural microbial food webs show that UVR can have effects beyond simple changes in species composition: UV-A plus UV-B can influence overall microbial community structure and thereby alter the trophic balance of autotrophic and heterotrophic processes.

It is important to place the effects observed at Lac à l'Eau Claire in the context of spectral UVR fluxes that are experienced in nature. Our experiments were conducted in the near-surface waters of the lake, and the microbial communities were therefore exposed to high solar UVR. Such conditions represent a 'worst case scenario' and are restricted to habitats that receive bright solar radiation for several days at a time such as shallow water columns or diurnal thermoclines. Nearsurface stratification may persist for many days in subarctic lakes (Milot-Roy \& Vincent 1993), but UVR effects are likely to be much reduced in deeper, wellmixed environments. For example, Jeffrey et al. (1996) found evidence of UV-B damage to bacterioplankton in the surface waters of the Gulf of Mexico, but only during calm seas; with moderate wind activity and mixing there was no net DNA damage, even at the surface. Despite the high. UVR dosages, the responses by the Lac a l'Eau Claire communities over $6 \mathrm{~d}$ were small relative to those typically reported in laboratory studies. Such studies are often conducted under artificially high irradiances, unusual spectral conditions and on organisms that have not been pre-acclimated to bright light. Our results imply that while laboratory studies may be useful for identifying mechanisms of cellular damage and some of their controlling variables, they are of more limited value in predicting the net effect on microbial food web structure in the natural aquatic environment.

Acknowledgements. We thank Sylvain Arsenault, Isabelle Laurion and Joshua Sala for their invaluable assistance at Lac à l'Eâu Claire, and Jacques Larochelle, Connie Lovejoy, JeanJacques Frenette and 4 anonymous reviewers for their comments on the manuscript. This work was supported by grants from the Natural Sciences and Engineering Research Council of Canada and the Ministry of Indian and Northern Affairs, with logistic support from Centre d'études nordiques. 


\section{LITERATURE CITED}

Andersson A, Haecky P, Hagström $\AA$ (1994) Effect of temperature and lighl on the growth of micro-, nano- and prcoplankton: impact on algal succession. Mar Biol 120: $511-520$

Arsenault S (1993) Hydrologie, météorologie, bathymétrie et morphométrie, Lac à l'Eau Clarre 1992. Département de biologie et Centre d'études nordiques, Université Laval, Sainte-Foy

Behrenfeld MJ, Lean DRS, Lee H II (1995) Ultraviolet-B radiation effects on inorganic nitrogen uptake by natural assemblages of oceanic plankton. J Phycol 31:25-36

Behrenfeld MJ, Lee H II, Small LF (1994) Interactions between nutritional status and long-term responses to ultraviolet-B radiation stress in a marine diatom. Mar Biol 118:523-530

Bothwell ML, Sherbot D, Roberge AC, Daley RJ (1993) Influonce of natural ultraviolet rartiatinn on lotic periphytic diatom community growth, biomass accrual, and species composition: short-term versus long-term effects. J Phycol $29: 24-35$

Coveney MF, Wetzel RG (1992) Effects of nutrients on specific growth rate of bacterioplankton in oligotrophic lake water cultures. Appl Environ Microbiol 58:150-156

Cullen JJ, Lesser MP (1991) Inhibition of photosynthesis by ultraviolet radiation as a function of dose and dosage rate results for a marine diatom. Mar Biol 111:183-190

Cullen JJ, Neale PJ (1994) Ultraviolet radiation, ozone depletion, and marine photosynthesis. Photosynth Res 39:303-320

Davidson AT, Marchant HJ, de la Mare WK (1996) Natural UVB exposure changes the species composition of Antarctic phytoplankton in mixed culture. Aquat Microb Ecol 10 299-305

Driscoll WC (1996) Robustness of the ANOVA and TukeyKramer statistical tests. Comp Ind Eng 31:265-268

Elser JJ, Stabler LB, Hassett RP (1995) Nutrient limitation of bacterial growth and rates of bacterivory in lakes and oceans: a comparatıve study. Aquat Microb Ecol 9 $105-110$

Environment Canada (1994) Analytical methods manual Inland Waters Directorate, Water Quality Branch, Ottawa

Frenette JJ, Vincent WF, Legendre L, Nagata T (1996) Sizedependent phytoplankton responses to atmospheric forcing in Lake Bıwa. J Plankton Res 18:371-391

Hall JA, Vincent IIF (1990) Vertical and horizontal structure in the picoplankton communities of a coastal upwelling system. Mar Biol 106:465-471

Herndl GJ, Müller-Niklas G. Frick J (1.993) Major role of ultraviolet-B in controlling bacterioplankton growth in the surface layer of the ocean. Nature 361:717-719

Hessen DO, van Donk E (1994) Effects of UV-radiation of humic water on primary and secondary production. Water Air Soll Pollut 75:325-338

Hessen DO, van Donk E, Andersen T (1995) Growth responses, P-uptake and loss of flagella in Chlamydomonas reinhardtu exposed to UV-B. J Plankton Res 17:17-27

Holm-Hansen O, Helbling EW (1993) Polyethylene bags and solar ultraviolet radiation. Science 259:533

IASC (1995) Effects of increased ultraviolet radiation in the Arctic. International Arctic Science Committee Report No. 2, Oslo

Jeffrey WH, Pledger RJ, Aas $P_{1}$, Hager $S$, Coffin RB, von Haven R, Mitchell DL (1996) Diel and depth profiles of DNA photodamage in bacterioplankton exposed to ambient solar ultraviolet radiation. Mar Ecol Prog Ser 137 $283-291$
Kalff J, Welch HE (1974) Phytoplankton production in Char Lake, a natural polar lake, and in Meretta Lake, a polluted polar lake, Cornwallis Island, Northwest Terntories. J Fish Res Bd Can 31.621-63.6

Karentz D (1991) Ecological considerations of Antarctıc ozone depletion. Antarct Sci 3:3-11

Karentz D. Cleaver JE, Mitchell DL (1991) Cell survival characteristics and molecular responses of Antarctic phytoplankton to ultraviolet-B radiation. J Phycol 27:326-341

Kerr JB (1994) Decreasing ozone causes health concern. Environ Sci Technol 28:514-518

Kirchman DL (1994) The uptake of inorganic nutrients by heterotrophic bacteria. Microb Ecol 28:255-271

Laurion I, Vincent WF, Lean DRS (1997) Underwater uItraviolet radiation: development of spectral models for northern high latitude lakes. Photochem Photobiol 65:107-114

Lovejoy $\mathrm{CL}$, Legendre L, Klein B, Tremblay JE, Ingram RG, Therriault JC (1996) Bacterial actıvity during early winter mixing (Gulf of St. Lawrence, Canada). Aquat Microb Ecol $10: 1-13$

Lovejoy CL, Vincent WF, Frenette JJ, Dodson JJ (1993) Microbial gradients in a turbid estuary: application of a new method for protozoan cornmunity analysis. Limnol Oceanogr 38:1295-1303

Milot-Roy V, Vincent WF (1994) UV radiation effects on photosynthesis: the importance of near-surface thermoclines in a subarctic lake. Arch Hydrobiol Beih Ergeb Limnol 43 $171-184$

Morris DP, Zagarese H, Williamson CE, Balseiro EG, Hargreaves BR, Modenutti B, Queimalinos C (1995) The attenuation of solar UV radiation in lakes and the role of dissolved organic carbon. Limnol Oceanogr 40:1381-1391

Müller-Niklas G, Heissenberger A, Puškarić S, Herndl GJ (1995) Ultraviolet-B radiation and bacterial metabolism in coastal waters. Aquat Microb Ecol 9:111-116

Nielsen T, Ekelund NGA (1993) Effect of UV-B radiation and humic substances on growth and motility of Gyrodinium aureolum. Limnol Oceanogr 38:1570-1575

Nusch EA (1980) Comparison of different methods for chlorophyll and phaeopigments determination. Arch llydrobiol Beih Ergeb Limnol 14:14-36

Pérez-Martinez C, Cruz-Pizarro L (1995) Species-specific phytoplankton responses to nutrients and zooplankton manipulations in enclosure experiments. Freshwater Biol 33:193-203

Porter KG, Feig YS (1980) The use of DAPI for identification and enumeration of bacteria and blue-green algae. Limnol Oceanogr 25:943-948

Prézelin BB, Boucher NP, Smith RC (1994) Marme primary production under the influence of the Antarctic ozone hole: Icecolors '90. In: Weller CS, Penhale PA (eds) Ultraviolet radiation and biological research in Antarctica. American Geophysical Union, Washington, DC. Antarct Res Ser 62:159-186

Quesada A, Mouget JL, Vincent WF (1995) Growth of Antarctic cyanobacteria under ultraviolet radiation: UVA counteracts UVB inhibition. J Phycol 31:242-248

Schindler DW (1974) Eutrophication and recovery in experimental lakes: implications for lakr management. Science $184: 897-899$

Schindler DW, Beaty KG, Fee EJ, Cruikshank DR, DeBruyn ER, Findlay DL, Linsey GA, Shearer JA, Stainton MP. Turner MA (1990) Effects of climatic warming on lakes of the central boreal forest. Science 250:967-970

Smith RC, Prézelin BB, Baker KS, Bidigare RR, Boucher NP, Coley T, Karentz D, Macintyre S, Matlick HA, Menzies D, Ondrusek M, Wan Z, Waters KJ (1992) Ozone depletion: 
ultraviolet radiation and phytoplankton biology in Antarctıc waters. Science 255:952-959

Smith VH, Rigler FH, Choulik O, Diamond M, Griesbach S, Skrada D (1984) Effects of phosphorus fertulization on phytoplankton retention in subarctic Quebec lakes. Verh Int Verein Theor Angew Limnol 22:376-382

Stockner JG, Shortreed KS (1991) Phototrophıc picoplankton: community composition, abundance and distribution across a gradient of oligotrophic Columbia and Yukon Territory lakes. Int Rev Ges Hydrobiol 76:581-601

Suttle CA, Stockner JG, Harrison PJ (1987) Effects of nutrient pulses on community structure and cell size of a freshwater phytoplankton assemblage in culture. Can J Fish Aquat Sci 44:1768-1774

Suttle CA, Stockner JG, Shortreed KS, Harrison PJ (1988) Time-courses of size-fractiondted phosphate uptake: are larger cells better competitors for pulses of phosphate than smaller cells? Oecologia 74:571-576

Takamura N, Nojiri Y (1994) Picophytoplankton biomass in relation to lake trophic state and the TN:TP ratio of lake water in Japan. J Phycol 30:439-444

Tsujı T, Yanagita Y (1981) Improved fluorescent microscopy for measuring the standing stock of phytoplankton includ. ing fragile components. Mar Biol 64:207-211

Responsible Subject Editor: J. Dolan, Villefranche-sur-Mer, France
Vincent WF, Plenitz R (1996) Sensitıvity of high latitude freshwater ecosystems to global climate change: temperature and solar ultraviolet radiation. Geosci Can 23:231-236

Vincent WF, Quesada A (1994) Ultraviolet radiation effects on cyanobacteria: implicatıons for Antarctic microbial ecosystems. In: Weiler CS, Penhale PA (eds) Ultraviolet radiation and bulogical research in Antarctica. American Geophysical Union, Washungton, DC. Antarct Res Ser 62:111-124

Vincent WF, Roy S (1993) Solar ultraviolet-B radiation and aquatic primary production: damage, protection and recovery. Environ Rev 1:1-12

Wehr JD (1989) Experimental tests of nutrient limitation in freshwater picoplankton. Appl Environ Microbiol 55: $1605-1611$

Weiler CS, Penhale PA (eds) (1994) Ultraviolet radiation and bjological research in Antarctica. American Geophysical Union, Washington, DC. Antarct Res Ser 62

Welch HE, Legault JA, Kling HJ (1989) Phytoplankton, nutrients, and primary production in fertilized and natural lakes at Saqvaqjuac, N.W.T Can J Fish Aquat Sci 46: $90-107$

Zweifel U. Hagström $\AA$ (1995) Total counts of marine bacteria include a large fraction of non-nucleoid containing bacteria (ghosts). Appl Environ Microbiol 61:2180-2185

Manuscript first received: December 9, 1996 Revised version accepted: March 4, 1997 